\title{
Crosslinking kezelés hatása a szaruhártya hámosodására
}

\author{
Gyenes Andrea dr. ${ }^{1}$. Szentmáry Nóra dr. ${ }^{1,2}$. Tóth Gábor dr. ${ }^{1}$ \\ Kiss Huba dr. ${ }^{1}$. Szekrényesi Csaba dr. ${ }^{3}$. Achim Langenbucher dr. ${ }^{4}$ \\ Nagy Zoltán Zsolt dr. ${ }^{1}$
}

\author{
'Semmelweis Egyetem, Általános Orvostudományi Kar, Szemészeti Klinika, Budapest \\ ${ }^{2}$ Klinik für Augenheilkunde, Universität des Saarlandes, UKS, Homburg/Saar \\ ${ }^{3}$ Semmelweis Egyetem, Egészségtudományi Kar, Budapest \\ ${ }^{4}$ Exprimentelle Ophthalmologie, Universität des Saarlandes, Homburg/Saar
}

\begin{abstract}
Bevezetés és célkitüzés: A crosslinking kezelés szaruhártya-hámosodásra gyakorolt hatásának vizsgálata. Betegek és módszer: Vizsgálatunkba 39 keratoconusos beteget vontunk be crosslinking kezelés után, és 11 pácienst fotorefraktív keratectomiát követően (kontroll) crosslinking kezelést követően 21, 45 és 69 órával. A festődő szaruhártyahám-hiány területét a fotorefraktív keratectomiát követően 16, 37 és 61 órával meghatároztuk. A fotorefraktív keratectomia kezelések utáni kontrollok időpontja nem egyezett a crosslinking kezelést követő kontrollidőpontokkal, így a fotorefraktív keratectomiás csoportnál a hámhiány feltehető méretét a crosslinking kezelési csoport mérési időpontjaira számítottuk, és $\chi^{2}$-teszt segítségével hasonlítottuk össze a két csoportban a hámhiány méretét. Eredmények: A cornea crosslinking kezelést követően a szaruhártya hámjának záródása a kezeléstől számított három napon belül, fotorefraktív keratectomiát követően négy napon belül következett be. 45 és 69 óra elteltével a két csoport között szignifikáns különbség igazolódott a hámhiány méretében $(\mathrm{p}=0,005$ és $\mathrm{p}<0,001)$. Következtetés: A crosslinking kezelést követően a szaruhártya hámosodása gyorsabb, mint fotorefraktív keratectomiát követően. Vizsgálatunk a crosslinking kezelés hámgyógyulásra kifejtett kedvező hatását igazolta. Orv. Hetil., 2017, 158(10), 376-379.
\end{abstract}

Kulcsszavak: crosslinking, fotorefraktív keratectomia, hámgyógyulás

\section{Impact of crosslinking on corneal epithelial healing}

Introduction and aim: To analyse the effect of crosslinking (CXL) on corneal epithelial healing. Patients and method: 39 keratoconus patients following CXL and 11 patients following PRK were enrolled in this study. 21, 45 and 69 hours after CXL and 16, 37 and 61 hours following PRK slitlamp photographs were taken using fluorescein staining and the size of the epithelial defect and the time of epithelial closure was determined. As the observation time-points differed in both groups, the size of the epithelial defect following PRK was calculated for the time points used for analysis of CXL patients. These data were compared using chi-quadrat test. Results: Following crosslinking, epithelial closure occured within 3, following PRK within 4 days. In the area of epithelial erosion 45 and 69 hours after CXL or PRK treatment statistically significant difference $(\mathrm{p}=0.005$ and $\mathrm{p}<0.001)$ was verified. Conclusion: Our results show beneficial effect of crosslinking on corneal epithelial healing.

Keywords: crosslinking, photorefractive keratectomy, corneal epithelial healing

Gyenes, A., Szentmáry, N., Tóth, G., Kiss, H., Szekrényesi, Cs., Langenbucher, A., Nagy, Z. Zs. [Impact of crosslinking on corneal epithelial healing]. Orv. Hetil., 2017, 158(10), 376-379.

(Beérkezett: 2016. november 14.; elfogadva: 2016. december 8.)

\section{Rövidítések}

$\mathrm{CXL}=$ crosslinking kezelés; PRK = fotorefraktív keratectomia; $\mathrm{SE}=$ szférikus ekvivalens; UVA = ultraviola sugárzás A
A crosslinking (CXL) technika a keratoconus progresszióját megállító eljárás. A módszert a drezdai Technische Universitäten fejlesztették ki. Elsőként Wollensak, Spoerl és Seiler alkalmazták humán corneákon [1]. 


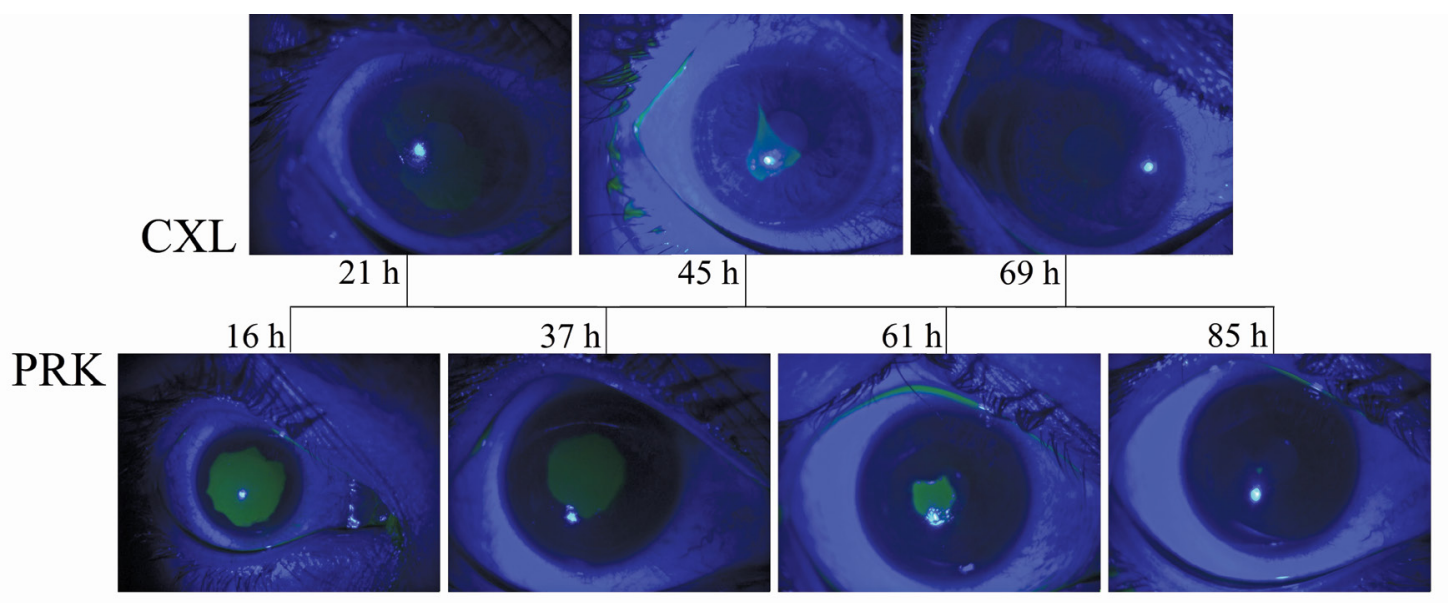

A crosslinking kezelés a szaruhártya stromájában elhelyezkedő kollagénrostok között növeli a kovalens kötések számát, így a kezelt corneák rigiditása kezeletlen szaruhártyákkal összevetve 70\%-kal nagyobb [2]. Crosslinking kezelés során a keresztkötések (crosslink) képződését fotokémiai reakció hozza létre. Az alkalmazott riboflavin fotoszenzibilizáló szer UVA-besugárzása oxigén-szabadgyökök keletkezéséhez vezet, és ennek hatására létesülnek a stromális kollagénrostok között kovalens kötések. A folyamat a polimerek fotopolimerizációjához hasonló [3].

Bár a CXL-kezelés elsődleges alkalmazási területe a progresszív keratoconus, a CXL-kezelések indikációs köre az utóbbi időben jelentősen bővült. Refraktív kezelés után kialakult keratectasiában [4], bullosus keratopathiában és pellucid marginális degenerációban [5] is történt ilyen kezelés.

Emellett mintegy tíz éve terápiarezisztens keratitisben és esetenként szaruhártyafekélyeknél is alkalmazzák, kihasználva antimikrobás és feltételezett hámosodást támogató hatását [6-10].

A CXL szaruhártya-hámosodást segítő hatásáról esettanulmányok születtek, azonban több beteget vizsgáló klinikai tanulmány ez idáig, tudomásunk szerint, nem található az irodalomban.

Jelen vizsgálatunkban célul tûztük ki a crosslinking kezelés szaruhártya-hámosodásra gyakorolt hatásának vizsgálatát klinikánk betegeinél.

\section{Betegek és módszer}

Vizsgálatunkba 39 keratoconusos (átlagéletkor: $31,92 \pm 8,43$ év) és 11 látásjavító célú, PRK (fotorefraktív keratectomia) kezelés előtt álló pácienst (átlagéletkor: $41,73 \pm 13,93$ év) vontunk be. A keratoconusos betegeknél topo- és tomográfiával igazolt progresszió miatt végeztünk CXL-kezelést. Kontrollcsoportnak a PRK-kezelésen átesett szemeket választottuk. A 11 PRK-keze- lésből tíz esetben myop kezelést végeztünk (szférikus ekvivalens: $\mathrm{SE}=-5,08 \pm 3,08$ ), egy esetben hypermetrop kezelés történt $(\mathrm{SE}=+3,5 \mathrm{D})$. Sem a crosslinkinggel kezelt, sem a látásjavító refraktív kezelt betegcsoportban nem volt ismert egyéb szembetegség, illetve korábbi szemmütét sem történt.

A hámeltávolítás CXL és PRK esetén is $9,0 \mathrm{~mm}$ átmérőjü területen történt hokikés segítségével, oxybuprocain-hidrokloriddal történő felszíni érzéstelenítést követően.

Ezután a crosslinkinggel kezelt szemeken $0,1 \%$-os riboflavinoldatot (Ricrolin, Sooft Italia, Olaszország) cseppentettünk a corneára $2-5$ percenként 30 percen keresztül. A szaruhártyára ezután $370 \pm 5 \mathrm{~nm}$ hullámhoszszú UV-fényt bocsátottunk, amelynek teljesítménye $3 \mathrm{~mW} / \mathrm{cm}^{2}$, a besugárzás időtartama pedig 30 perc volt. Így a corneára eső összes energia $3,4 \mathrm{~J}$, a teljes sugárexpozíció $5,4 \mathrm{~J} / \mathrm{cm}^{2}$ volt (CSO Vega CMB X Linker, CSO Scandicci, Firenze, Olaszország). A PRK-csoportban a hámabrasiót követően $6,0 \mathrm{~mm}$ átméróben a Meditec MEL 80 excimer lézerrel (Zeiss, Jéna, Németország) történt a fotoablatio.

CXL- és PRK-kezelést követôen a betegeknél kontaktlencsét nem illesztettünk, és a betegek posztoperatív lokális antibiotikum-kezelése nem különbözött (napi $5 \times 1$ levofloxacin hét napon át).

CXL-kezelést követően 21, 45 és 69 órával, PRK-t követóen 16, 37 és 61 órával a szaruhártyáról nátrium-fluoreszceinnel történt festést követően réslámpás felvételt készítettünk (1.ábra). A készített felvételen meghatároztuk a festődő terület nagyságát a teljes corneafelülethez viszonyítva, illetve rögzítettük a hám megfigyelt záródási idejét. A hámhiány területét az átlagos corneaátmérőből $(11,5 \mathrm{~mm})$ számolt teljes felszín területéből számoltuk ki a hámhiány területére illesztett rácsmintázat segítségével. A corneafelszínre egyforma négyzetekből álló négyzetrácsos mintázatot illesztettünk, az így kapott teljes felszínhez tartozó négyzetek számát a hámhiány területének megfelelő négyzetrácsot alkotó négy- 
1. táblázat |A hámhiány mérete a vizsgált csoportokban az egyes időpontokban $\left(\mathrm{mm}^{2}\right)$

\begin{tabular}{|c|c|c|c|c|c|c|c|c|}
\hline & & \multicolumn{7}{|c|}{ A hámhiány mérete $\left(\mathrm{mm}^{2}\right)$} \\
\hline & & 16 óra & 21 óra & 37 óra & 45 óra & 61 óra & 69 óra & 85 óra \\
\hline \multirow[t]{3}{*}{ CXL } & Átlag & & 15,57 & & 2,93 & & 0 & 0 \\
\hline & SD & & 7,93 & & 3,94 & & 0 & 0 \\
\hline & Medián & & 16,07 & & 1,35 & & 0 & 0 \\
\hline \multirow[t]{3}{*}{ PRK } & Átlag & 46,02 & $26,74^{*}$ & 15,72 & $11,7^{*}$ & 3,88 & $4,68^{*}$ & 0,53 \\
\hline & SD & 12,54 & $9,59 *$ & 8,59 & $6,92 *$ & 4,17 & $4,98^{*}$ & 1,22 \\
\hline & Medián & 43,75 & $27,84^{*}$ & 18,75 & 13,89 * & 3,55 & $4,44^{*}$ & 0,0 \\
\hline$\chi^{2}$-teszt & & & $p>0,05$ & & $\mathrm{p}=0,0$ & & $\mathrm{p}<0,00$ & \\
\hline
\end{tabular}

* Számított értékek.

$\mathrm{CXL}=$ crosslinking kezelés; PRK = fotorefraktív keratectomia; $\mathrm{SD}=$ standard deviáció

zetek számával összevetve megkaptuk a hámhiány területét a cornea teljes felszínéhez viszonyítva. A hányadost az átlagos corneaátmérőből $(11,5 \mathrm{~mm})$ számolt teljes corneafelszínnel megszorozva kaptuk meg a hámhiány területét.

Mivel a két betegcsoportban a hámhiány méretmeghatározásának posztoperatív időpontja nem egyezett, a PRK-kezelt betegek csoportjában a hámhiány feltehető méretét a CXL-kezelt betegek időpontjainak megfelelően kalkuláltuk. Az így kapott adatokat $\chi^{2}$-teszt segítségével hasonlítottuk össze a két vizsgált csoportban.

\section{Eredmények}

A hámhiány méretét a vizsgált időpontokban, valamint a számított hámhiányméreteket a PRK-csoportban az 1. táblázat tartalmazza. Az első posztoperatív napon, 21 óra elteltével még mindkét csoportban az összes szemen hámhiány volt megfigyelhető. A második posztoperatív napon, 45 óra elteltével a CXL-csoportból 13 esetben záródott a hám, a PRK-csoportban még továbbra is minden esetben volt hámhiány. A harmadik posztoperatív napon, 69 óra elteltével a CXL-csoportban minden szaruhártya behámosodott, a PRK-csoportból három szem behámosodott, nyolc szemen továbbra is volt hámhiány. A CXL-csoportban a harmadik posztoperatív napra (69 óra), a PRK-csoportban a negyedik posztoperatív napra ( 85 óra) következett be a hám záródása minden esetben. A statisztikai számításhoz alkalmazott $\chi^{2}$-teszt a két csoport között 45 óra és 69 óra elteltével szignifikáns különbséget igazolt a hámhiány méretében $(\mathrm{p}=0,005$ és $\mathrm{p}<0,001)$.

\section{Megbeszélés}

Vizsgálatunk célja volt, hogy a CXL-kezelés hámgyógyulásra kifejtett hatását értékeljük.

A szaruhártya hámgyógyulása három egymással összefüggő fázisból tevődik össze [11-14]. Cornealis hámhiány keletkezésekor a gyógyulási folyamat első 4-6 órájá- ban játszódik le a latens fázis, amelynek során a basalis epithelsejtek migrációja zajlik a sebszélről [15]. A sebfelszínen lévő sejttörmelékeket a könnyfilmből származó polimorfonukleáris leukocyták távolítják el [16]. Ezt követi a migrációs fázis, amely monolayer sejtréteg kialakulásával és sejtkapcsoló elemek képződésével jár [17]. A corneaeróziók utáni hámgyógyulást vizsgálva megállapították, hogy a szimmetrikusan létrejövő kétoldali hámzáródás sebessége a sebszél minden pontján egyformának tekinthető $[15,18]$. A folyamat végén a proliferációs fázisban épül ki a végleges hámvastagság. A hámgyógyulást befolyásoló faktorok közül kiemelendő a hámhiány mérete és mélysége, illetve a felszínen lévő egyenetlenségek [19]. Emellett a könnyfilm minősége és integritása is meghatározó tényezői a sebgyógyulási folyamatnak [20].

A hámgyógyulást különböző faktorok befolyásolják, ezek közül a seb paraméterei közül annak nagysága, mélysége és a sebalap felszíni minősége kiemelendő [21, 22]. A hámosodás sebessége fajonként is eltér. Vizsgálatunkban a két összehasonlított csoport a felszín morfológiájában, valamint a Bowman-membrán meglétében különbözött egymástól, amelyek a felszíni hámosodásra befolyást gyakorolnak. A kontrollcsoportként választott PRK-csoportban fotoablatio is történt, míg CXL során csak a felszíni hámréteg került eltávolításra. A Bowmanmembrán sebgyógyulásban betöltött szerepe jelen álláspont szerint nem egyértelmü [23]. Egyes esetekben PRK-kezeléseket követően megfigyelték a Bowmanmembránhoz hasonló réteg újraképződését [23].

Jelen eredményeink szerint a CXL-t követően a hámeltávolítást követő harmadik napra következik be a szaruhártya epitheliumának záródása, és a teljes behámosodás gyorsabban történik, mint PRK-t követően. Egy korábbi tanulmányban Khan szintén a szaruhártyahámhiány gyógyulásáról számolt be crosslinking kezelést követően, terápiarezisztens Acanthamoeba-keratitisben [24]. Al-Sabai a szaruhártya beolvadásában tapasztalta a gyulladásos jelek megszûnését és a szaruhártya behámosodását [25], valamint Tóth és mtsai Boston keratoproté- 
zis körüli szaruhártya-beolvadás sikeres crosslinking kezeléséról számoltak be [26].

Ezzel szemben egy kísérletes tanulmányban a CXL hatását humán sejtvonalon vizsgálva a riboflavinkoncentráció és UVA-sugárzás cornealis epithelsejtek proliferációját és migrációját nem befolyásolta [27]. Ugyanakkor az in vitro vizsgálati eredmények nem minden esetben vethetők össze a klinikai tapasztalattal. Jelen eredményeink alapján felmerül a CXL pozitív hatása akár egyes, a sebgyógyulás zavarával járó kórállapotokban is.

\section{Következtetés}

A gyorsabb hámgyógyulás korábban helyreálló látóélességgel, kevesebb diszkomforttal és hamarabb helyreálló barrierfunkcióval jár együtt, amit elősegíthet a CXL-kezelés alkalmazása. Mindazonáltal további vizsgálatok szükségesek olyan esetekben, ahol abrázió igen, ablatio viszont nem történik.

Anyagi támogatás: A közlemény megírása, illetve a kapcsolódó kutatómunka anyagi támogatásban nem részesült.

Szerzői munkamegosztás: Gy. A.: Adatgyújtés, vizsgálat lefolytatása, vizsgálati adatok feldolgozása, kézirat megszövegezése. Sz. N.: Hipotézis kidolgozása, vizsgálat lefolytatása, vizsgálati adatok feldolgozása, statisztikai elemzések, kézirat megszövegezése. T. G., K. H., Sz. Cs.: Adatgyưjtés. A. L..: Vizsgálati adatok feldolgozása, statisztikai elemzések. N. Z. Zs.: Hipotézis kidolgozása, crosslinking kezelések elvégzése, vizsgálat lefolytatása. A cikk végleges változatát valamennyi szerző elolvasta és jóváhagyta.

Érdekeltségek: A szerzőknek nincsenek érdekeltségeik.

\section{Irodalom}

[1] Wollensak, G., Spoerl, E., Seiler, T.: Riboflavin/ultraviolet-A induced collagen crosslinking for the treatment of keratoconus. Am. J. Ophthalmol., 2003, 135(5), 620-627.

[2] Spoerl, E., Schreiber, J., Hellmund, K., et al.: Studies on the stabilization of the cornea in rabbits. [Untersuchungen zur Verfestigung der Hornhaut am Kaninchen.] Ophthalmologe, 2000, 97(3), 203-206. [German]

[3] Hettlich, H. J., Lucke, K., Kreiner, C. F.: Light-induced endocapsular polymerization of injectable lens refilling materials. Ger. J. Ophthalmol., 1992, 1(5), 346-349.

[4] Hafezi, F., Kanellopoulos, J., Wiltfang, R., et al.: Corneal collagen crosslinking with riboflavin and ultraviolet $A$ to treat induced keratectasia after laser in situ keratomileusis. J. Cataract Refract. Surg., 2007, 12(12), 2035-2040.

[5] Kymionis, G. D., Portaliou, D. M., Bouzoukis, D. I., et al.: Herpetic keratitis with iritis after corneal crosslinking with riboflavin and ultraviolet A for keratoconus. J. Cataract Refract. Surg., 2007, 33(11), 1982-1984.

[6] Makdoumi, K., Mortensen, J., Crafoord, S.: Infectious keratitis treated with corneal crosslinking. Cornea, 2010, 29(12), 13531358.
[7] Morén, H., Malmsjö, M., Mortensen, J., et al.: Riboflavin and ultraviolet A collagen crosslinking of the cornea for the treatment of keratitis. Cornea, 2010, 29(1), 102-104.

[8] Iseli, H. P., Thiel, M. A., Hafezi, F., et al.: Ultraviolet A/riboflavin corneal cross-linking for infectious keratitis associated with corneal melts. Cornea, 2008, 27(5), 590-594.

[9] Panda, A., Krishna, S. N., Kumar, S.: Photo-activated riboflavin therapy of refractory corneal ulcers. Cornea, 2012, 31(10), 1210-1213.

[10] Zhang, Z. Y.: Corneal cross-linking for the treatment of fungal keratitis. Cornea, 2013, 32(2), 217-218.

[11] Ren, H., Wilson, G.: The cell shedding rate of the corneal epithelium - a comparison of collection methods. Curr. Eye Res., 1996, 15(10), 1054-1059.

[12] Daniels, J. T., Dart, J. K., Tuft, S. J., et al.: Corneal stem cells in review. Wound Repair Regen., 2001, 9(6), 483-494.

[13] Gaffney, E. A., Maini, P. K., Sherratt, J. A., et al.: The mathematical modelling of cell kinetics in corneal epithelial wound healing. J. Theor. Biol., 1999, 197(1), 15-40.

[14] Zieske, J. D., Gipson, I. K.: Agents that affect corneal wound healing: modulation of structure and function. In: Albert, D. M., Jacobiec, F. A. (eds.): Principles and practice of ophthalmology. 2nd ed. WB Saunders, Philadelphia, 2000, 364-372.

[15] Crosson, C. E., Klyce, S. D., Benerman R. W.: Epithelial wound closure in the rabbit cornea. A biphasic process. Invest. Ophthalmol. Vis. Sci., 1986, 27(4), 464-473.

[16] Lu, L., Reinach, P. S., Kao, W. W.: Corneal epithelial wound healing. Exp. Biol. Med. (Maywood), 2001, 226(7), 653-664.

[17] Gipson, I. K., Spurr-Michaud, S. J., Tisdale, A. S.: Hemidesmosomes and anchoring fibril collagen appear synchronously during development and wound healing. Dev. Biol., 1988, 126(2), 253-262.

[18] Estil, S., Kravik, K., Haaskjold, E., et al.: Pilot study on the time course of apoptosis in the regenerating corneal epithelium. Acta Ophthalmol. Scand., 2002, 80(5), 517-523.

[19] Steele, C.: Corneal wound healing: A review. Part I. Optometry Today, 1999, 24, 28-32.

[20] Klenkler, B., Sheardown, H., Jones, L.: Growth factors in the tear film: role in tissue maintenance, wound healing, and ocular pathology. Ocul. Surf., 2007, 5(3), 228-239.

[21] Lombardo, M., Serrao, S.: Smoothing of the ablated porcine anterior corneal surface using the Technolas Keracon 217C and Nidek EC-5000 excimer lasers. J. Refract. Surg., 2004, 20(5), $450-453$

[22] Steele, J. G., Johnson, G., McLean, K. M., et al.: Effect of porosity and surface hydrophilicity on migration of epithelial tissue over synthetic polymer. J. Biomed. Mater. Res., 2000, 50(4), 475482.

[23] Wilson, S. E., Hong, J. W.: Bowman's layer structure and function: critical or dispensable to corneal function? A hypothesis. Cornea, 2000, 19(4), 417-420.

[24] Khan, Y. A., Kashiwabuchi, R. T., Martins, S. A., et al.: Riboflavin and ultraviolet light a therapy as an adjuvant treatment for medically refractive Acanthamoeba keratitis: report of 3 cases. Ophthalmology, 2011, 118(2), 324-331.

[25] Al-Sabai, N., Koppen, C., Tassignon, M. J.: UVA/riboflavin crosslinking as treatment for corneal melting. Bull. Soc. Belge Ophtalmol., 2010, 315, 13-17.

[26] Tóth, G., Bucher, F., Siebelmann, S., et al.: In situ corneal crosslinking for recurrent corneal melting after Boston Type 1 keratoprosthesis. Cornea, 2016, 35(6), 884-887.

[27] Wu, M. F., Stachon, T., Wang, J., et al.: Effect of keratocyte supernatant on epithelial cell migration and proliferation after corneal crosslinking (CXL). Curr. Eye Res., 2016, 41(4), 466-473.

(Gyenes Andrea dr., Budapest, Mária utca 39., 1085 e-mail: gyenesandi@gmail.com) 